\title{
France, Australia left in cold
}

\section{Parls}

AfTer ten days of intense deliberation, the fifteenth international Antarctic Convention Consultative Meeting came to an end in Paris last Friday still profoundly divided over the best way to safeguard the future of the continent. The 25 consultative parties and the 13 contracting parties to the Antarctic Treaty failed to achieve the unanimity required to adopt the Convention on the Regulation of Antarctic Mineral Resource Activities (CRAMRA).

CRAMRA was drafted at the initiative of New Zealand to fill a gap in the existing Antarctic Treaty regarding mineral exploration and exploitation, activities that are at present technically disallowed but not controlled. CRAMRA proposes to allow exploration, but only if stringent environmental rules are followed. Having signed the draft convention, France and Australia have since refused to ratify it, and want instead to turn Antarctica into a natural wilderness reserve and 'land of science', where all but approved scientific projects would be banned.

Two clear factions emerged in Paris, with New Zealand, the United States and Britain calling for the adoption of CRAMRA and Belgium, Italy, Greece and Austria supporting the Franco-Aus-

ROCKEFELLER PRESIDENT

\section{Baltimore accepts, amid controversy}

\section{Washington}

THE Rockefeller University announced last week that David Baltimore, director of the Whitehead Institute in Cambridge, Massachusetts, since it was founded in 1982, will replace Joshua Lederberg as president of the university on 1 July 1990, when Lederberg retires. Baltimore, a Rockefeller alumnus, says his plans include "increasing the teaching role of the university, ... bringing the Rockefeller community more sense of

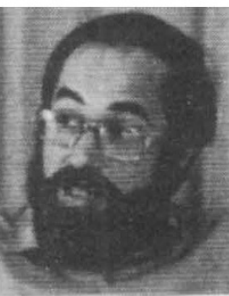
common purpose, increasing the role of younger scientists, and positioning the university to lead the way in understanding the nervous system".

Rockefeller's offer to Baltimore at first created controversy. Members of the faculty protested that Baltimore's links with the highly publicized misconduct allegations arising from a paper that he co-authored would damage the university's reputation. But Baltimore is said to have won over the opposition at a discussion with the faculty. Christine McGourty tralian recommendation. The proCRAMRA lobby says sufficient environment safeguards exist within two annexes to the Antarctic Treaty and in the new convention.

At the same time, they say, the FrancoAustralian proposals threaten to undermine the spirit of unanimity which has allowed the treaty to work well so far, while creating a parallel structure which, at the moment, lacks an appropriate administrative body.

But as a concession to the FrancoAustralian axis, the Paris meeting recommended that a Special Antarctic Treaty Consultative Meeting be held in mid-1990 specifically to discuss the protection of the environment and dependent ecosystems. In a second recommendation, the section of CRAMRA devoted to environmental protection will also be the subject of a meeting next year.

Commander Jacques-Yves Cousteau, marine biologist and a campaigner for the idea of an Antarctic wilderness reserve, was visibly disappointed at the outcome of the meeting. "We haven't advanced one iota", he said, blaming "bureaucrats from foreign affairs ministries who think the Antarctic is their thing".

But some positive measures were adopted, including a new code of practice for the disposal of waste created by scientific missions - ironically one of the major sources of Antarctic pollution. A recommendation to control marine pollution and the creation of a new category of protected area - of 'general interest' were also approved.

\section{Washington}

THE deputy director of the National Institute of Child Health and Human Development, Antonia Novello, is likely to be the next surgeon-general of the United States, replacing the forthright $\mathrm{C}$. Everett Koop who left earlier this year. Selection of a replacement has been slow, it is said because of the importance of finding a candidate who supported President Bush in his opposition to abortion.

Although her nomination, which would have to be confirmed by Congress, has not been formally announced by the Bush administration, Novello, a specialist in paediatric AIDS and known for her support of women's issues, is said to be the leading candidate.

Christine McGourty

Cousteau nevertheless sees next year's special meeting as a small victory and says it will give France and Australia time to prepare a more cogent proposal. $\mathrm{He}$ denied that France and Australia have upset the previous unanimity that allowed CRAMRA to be drafted. On the contrary, he said, the new lack of unanimity is a sign that CRAMRA should be dropped. Speaking on Saturday, he claimed that CRAMRA is, in any case, premature: "no one is currently interested in commercial mineral exploration in the Antarctic". Meanwhile, he said, nations would serve the interests of Antarctica better by tackling real threats to the Antarctic environment, posed by uncontrolled shipping and aircraft in the area.

The sixteenth Consultative Meeting will be held in West Germany in 1991.

Peter Coles AIDS

\section{European trials of AZT to continue}

\section{Paris}

AN Anglo-French placebo-controlled clinical trial of AZT in people infected with HIV (human immunodeficiency virus) but showing no symptoms of AIDS proper is to continue despite the short-term positive results that led a similar trial in the United States to be abandoned (see Nature 340, $581 ; 1989$ ) The trial, called Concorde 1 , is jointly sponsored by the British Medical Research Council and the French Institut National de la Santé et de la Recherche Medicale (INSERM).

After the apparent success in the US trial of AZT in slowing progression to AIDS and advanced AIDS-related complex in individuals with a T4 cell-count of less than 500 , the US National Institute of Allergies and Infectious Diseases (NIAID) ordered a halt to the trial. Since then, AZT (or Zidovudine in France), has been approved by the US Food and Drug Administration for use with individuals in an early stage of HIV

\section{infection.}

After discussions with NIAID officials, the Data and Safety Monitoring Committee (DSMC) of the Concorde 1 study has decided that "the scientific data now available do not allow strict recommendations to be made about Zidovudine treatment of asymptomatic HIV positive people based on their CD4 lymphocyte counts. This applies equally to people in trials and in clinical practice."

According to Professor Jean Dormont, of the INSERM immunopathology unit at Clamart near Paris, the US data are not in question, but allow no conclusions about AZT in asymptomatic HIV-infected individuals. "The DSMC has advised us to continue the trial in order to try to obtain longer-term results. But we will leave it to each participating centre to decide, as a matter of conscience, whether it is appropriate to put an individual onto AZT with a T4 count of 500 or not". Peter Coles 